\title{
Observed Foreign Body Indicator
}

National Cancer Institute

\section{Source}

National Cancer Institute. Observed Foreign Body Indicator. NCI Thesaurus. Code C147151.

An indication as to whether a foreign body is present in the body. 